\title{
DEVELOPING ENGLISH SUPPLEMENTARY LOCAL WISDOM-BASED LISTENING MATERIALS USING NATURAL READER 14 APPLICATION
}

\author{
L. Suryani ${ }^{1}$, I N. A. Putra², L. P. Artini ${ }^{3}$ \\ 1,2,3 Universitas Pendidikan Ganesha
}

e-mail: luhsuryanieed@gmail.com, in_adijayaputra@undiksha.ac.id,putu.artini@undiksha.ac.id

\begin{abstract}
This study aimed at a) describing the topics needed to be developed for English supplementary local wisdom-based listening materials for the eighth grade students based on Curriculum 2013 at SMP Negeri 2 Singaraja; b) describing the process of developing the English supplementary local wisdom-based listening materials for the eighth grade students at SMP Negeri 2 Singaraja; c) assessing the quality of the developed product. This study implemented Design and Development research by Richey and Klein (2007). The phases were analysis, design, development, and evaluation. The data were obtained from document study, observation sheet, interview guide, questionnaire and a scoring rubric. The data were analyzed qualitatively and quantitatively. The results of this study show that (a) the developed topics are (1) giving and responding to compliment, (2) asking and giving opinions, (3) asking and giving information about ability and willingness, (4) asking and giving information about a must, prohibition, and suggestions, (5) asking and giving instruction, invitation, and permission, (6) asking and giving information about special events or days, (7) asking and giving information about the location, things, and animals; (b) the processes of developing the materials are analyzing the English syllabus, four potencies of local wisdom of Bali, and present situation at SMPN 2 Singaraja, designing a blue print of the product, developing a blue print into a complete listening materials, and evaluating the developed materials by four expert judges; (c) the result of product evaluation done by the four expert judges shows that the developed product is categorized as excellent materials. The outcome of this study is the product which is in the form of audio recording (CD-RW) and the printed listening materials along with the answer key and listening scripts.
\end{abstract}

Keywords: supplementary materials, local wisdom, listening, Curriculum 2013

\section{INTRODUCTION}

The integration of four language skills should be considered since they have a great relationship in language teaching and learning and a real-life communication. When people or children engage in conversations, the first language skill that they require was listening. They will listen first before being able to speak in a conversation or communication. Renukadevi (2014), and Hu (2012) stated that listening is the most significant part of communication and the most frequently used language skill as it is pivotal in providing and helping the learners to acquire pronunciation, word stress, vocabulary, the comprehension of messages conveyed based on tone of voice, pitch and accent; and it is only possible when they listen. Thus, listening is seen as the most important language skill since listening skill is considered as a starting point in learning a language and used in a real-life communication.

In mastering those four language skills, especially listening skill, learners should learn and practice it more. It is teacher's job to provide and create good listening materials for learners to practice their listening based on the Curriculum implemented at school. The newest curriculum in Indonesia is Curriculum 2013. There are some components of syllabus in Curriculum 2013, one of them is learning 
materials. They are very important since they are fundamental and essential to education as the primary tools that schools use to provide students with access to the knowledge and skills they are expected to learn (Oakes, 2002). To know the use of listening materials at SMP Negeri 2 Singaraja, pre-observation and interview were done. The results showed that the English teachers had difficulty in teaching listening since listening materials were not adequately available that used native speaker voices and were suitable with the topics and the eighth grade students, the same and old strategy in teaching listening was used by the English teachers through reading a short paragraph or text, and the listening materials especially on the exercises used by the English teachers did not consider the implementation of local wisdom of Bali as the local potential of the students' place of origin. Sehe, Tolla, Kamaruddin \& Hamsa (2016) also found the same problems in their study, thus they had developed language learning materials based on local wisdom. Therefore, in this study, those three problems became a consideration in developing these English supplementary listening materials for the eighth grade students to support the existed main English book (Buku Paket) as the additional practices especially for listening activities since the main English book did not provide a variety of listening practices for the students that used native-like speaker voices.

In developing listening materials, they should be developed based on the nearest context of the students. It is arranged in the Indonesia Law of National Education System Number 20 Year 2003 act 36 about Curriculum and Regulation of Minister of Education and Culture Number 81A Year 2013 about the implementation of curriculum. It is stated that education in Indonesia needs to be correlated to diversity of the local potential, learners' potential, local identity and nation character. Sukandi (2013) claimed that language teaching has been placed in the form of localized approach which means that Indonesian EFL learners learn how to use English to communicate with other speakers of English globally without losing their identity as
Indonesians or Balinese or Javanese who have diversity in terms of their local cultures, religions, histories, and local wisdoms. Therefore, the context of local wisdom of Bali was inserted in the developed supplementary listening materials in this study.

According to Padmanugraha (2010), local wisdom is the knowledge that is discovered by local people through the accumulation of experiences and integrated with the understanding of surrounding nature and culture. Types of local wisdom are cultural artifacts of the local people such as, food, housing, medicine, cloth, literature, songs, music, and many others. Regarding the implementation about the local wisdom of Bali in this listening material, it was intent on developing listening materials which were more contextual for the eighth grade students in order to help them in learning values of their culture and local potencies during the process of listening. It is supported by Kurniawati, Wahyuni and Putra (2017) who stated that the use of local wisdom in learning materials help the students to understand concepts in contextual and correct, and through local wisdom, students can learn the values of the culture and sense of nationalism that may affect learning outcomes (attitudes, behavior, and thinking ability). Therefore, in this study, local wisdom of Bali was inserted in developing this listening materials based on four potencies of the development of local wisdom proposed by Sehe, Tolla, Kamaruddin, and Hamsa (2016), such as, natural resources potency, human resources potency, geographical potency, and historical potency of Bali. They were inserted as a basic information in the content of the exercises in the developed supplementary listening materials.

Some researchers have conducted studies on the development of listening materials in teaching and learning. The previous studies were from Nawangsasi (2015) and Rakhmawati, Iragiliati and Rachmajanti (2016). Nawangsasi (2015) has conducted a study on developing materials of listening comprehension for the English Department students. This study was designed as Research and Development study (R \& D) by Jolly and 
Bolitho (in Tomlinson, 1998). This study developed 4 units of materials based on Curriculum 2013. Considering the students' learning needs, the inputs of the materials are in the form of videos, audios, pictures, explanations, and vocabulary list. Rakhmawati, Iragiliati and Rachmajanti (2016) have also conducted a study on developing supplementary multimedia-based listening materials for the seventh graders in second semester using scientific approach Curriculum of 2013.

Accordingly, this study, with the same focus as the study above, used Research and Development model by Dick and Carey (2001) with the multimedia-based materials development model by Kinney and Bruck (2009). The final product of this study was in macromedia flash file attached inside CDs/DVDs. By considering the previous studies, this study conducted the same topic of study on developing listening materials, but the differences were in terms of research design used, the amount of unit developed, the use of a sophisticated text-to-speech application, and also the context inserted in the content of the exercises in the developed listening materials.
Regarding to the background of this study, three research questions formulated were (a) What topics of English local wisdombased listening materials needed to be developed using Natural Reader 14 application for the eighth grade students based on Curriculum 2013 at SMP Negeri 2 Singaraja? (b) What are the processes of developing English local wisdom-based listening materials for the eighth grade students based on Curriculum 2013 at SMP Negeri 2 Singaraja? (c) What is the quality of the developed product? The research objectives were (a) to describe the topics of English supplementary local wisdom-based listening materials using Natural Reader 14 application for eighth grade students based on Curriculum 2013 at SMP Negeri 2 Singaraja, (b) to describe the process of developing English supplementary local wisdom-based listening materials for eight grade students based on Curriculum 2013 at SMP Negeri 2 Singaraja, (c) to assess the quality of the developed product.

\section{METHOD}

This study was designed in the form of Design and Development research by Richey and Klein (2007). This model was illustrated on Figure 1.

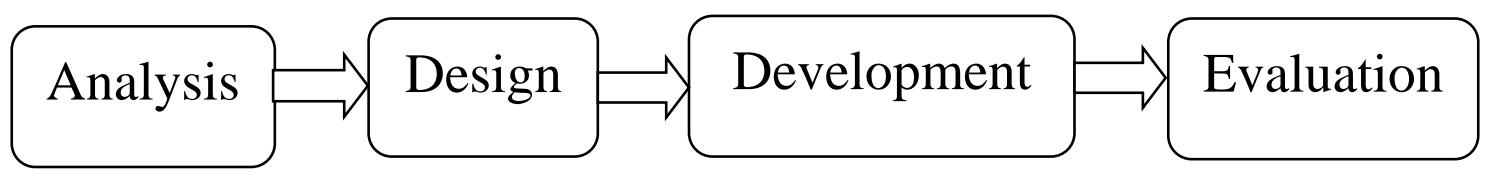

Figure 1: Richey and Klein's Model (2007, p. 8)

Richey and Klein's model consisted of four phases. Each of those phases was explained below.

a. Analysis

In this phase, the researcher and the English teachers analyzed the English syllabus of the eighth grade which was based on Curriculum 2013 in order to get the topics for listening materials. After that, the researcher and the English teachers at SMP Negeri 2 Singaraja mapped out the appropriate topics that needed to be supplemented with the local wisdom-based listening materials. Moreover, the researcher also analyzed and mapped out the four potencies of local wisdom of Bali, and analyzed present situation about the implementation of listening activity at SMP Negeri 2 Singaraja through interview, class observation, and giving questionnaire.

b. Design

The first step in this stage was to develop the blue print. The blue print of this developed English local wisdom-based listening materials consisted of unit, the topic, indicators, the potency of local wisdom inserted, and listening materials. The second step was to design English local wisdom-based listening materials by combining the result of analysis and 
mapping out from syllabus and the potencies of local wisdom in Bali. The draft of the design of English supplementary local wisdom-based listening materials was the result of this phase which was put into a table as a blue print.

c. Development

After designing listening materials, the researcher developed them all become printed listening materials and audio recording (CD-RW) for listening activity for the eighth grade students. The printed listening materials and audio recording consisted of seven units which are based on Curriculum 2013. Each unit in the printed listening materials covered the title/topic, competences to be achieved, learning instruction, content of learning materials, grammar focus, pronunciation focus, exercises, working instructions of each exercise, and assessment of the exercises. While, for the audio recording of the developed materials, the speed was arranged in accordance with the level of the eighth grade students. The speed provided in Natural Reader 14 application is in the range of 0 to 10 in which 0 is the fastest speed and 10 is the slowest speed. For this study, the speed of audio recording implemented in the developed listening materials for the eighth grade students was arranged intentionally on the range of 3 .

d. Evaluation

Evaluation was the last process of this study. At last, after developing this English local wisdom-based listening materials, they were evaluated by four expert judges in order to know the quality of the developed English local wisdom-based listening materials. These four expert judges were two expert lecturers from Ganesha University of Education who have the expertise and a lot of experiences in this field and two English teachers who teach the eighth grade students at SMPN 2 Singaraja.

This study was conducted at SMPN 2 Singaraja in the academic year of 2017/2018. The participants were two English teachers who teach the eighth grade students and fifteen classes which consisted of 557 of the eighth grade students at SMPN 2 Singaraja in the academic year of $2017 / 2018$.

In collecting the data, document study was used as a guidance to determine topics of listening activities that were developed. Direct observation to the classroom and interview with the English teachers who teach the eighth grade students were also conducted. Besides that, a questionnaire was given to the eight grade students at SMP Negeri 2 Singaraja to acquire the data about listening activities that the students like in listening class and students' perceptions on the listening activities created by their English teachers.

The data were analyzed qualitatively from document study, observation sheet, interview guide and questionnaire that were elaborated and explained to find topics, materials, and activities to develop listening materials for the eighth grade students. Meanwhile, the result of four expert judges' assessment were calculated quantitatively. The score is rated into Excellent, Good, Average, Below Average and Poor. A formula used to evaluate the result of the expert judges' assessment was a formula proposed by Candiasa (2010).

\section{FINDINGS AND DISCUSSION}

In this study, the three main findings were about the topics need to be developed, the process of developing the English supplementary local wisdom-based listening materials, and the quality of the developed product examined by four expert judges. In the first finding, there were two aspects that were analyzed. The first was the topics used in the developed listening materials and the second was the four main potencies of the development of local wisdom that were especially specified into the aspects of Balinese local wisdom. The result of analyzing document study identified seven topics which were suitable to be developed in listening materials for the eighth grade students and were suitable to be developed with the insertion of Balinese local wisdom. The topics were (a) giving and responding to compliment, (b) asking and giving opinions, (c) asking and giving information about ability and willingness, (d) asking and 
giving information about a must, prohibition, and suggestions, (e) asking and giving instruction, invitation, and permission, ( $f$ ) asking and giving information about special events or days, (g) asking and giving information about the location, things and animals. Some studies were also developed these topics. Qodir, Baehaqi and Miftah (2016) developed some topics in their study which were same as in this study, such as asking and giving information about ability \& willingness; asking \& giving information about a must, prohibition, and suggestions; asking and giving instruction, invitation, and permission; and asking \& giving information about the location, things, and animals. While, Nawangsasi (2015) developed two same topics as in this study, such as giving and responding to a compliment and asking and giving opinions. Syafi'i (2016) and Rakhmawati, Iragiliati and Rachmajanti (2016) developed a same topic as in this study, namely asking and giving instruction, invitation, and permission. In addition, Mahaputri (2017) developed two same topics as in this study, such as asking \& giving information about special events/days, and asking \& giving information about the location, things, and animals.

Meanwhile, there were thirteen listening activities implemented in the developed listening materials based on students' choice on the questionnaire. Those were: 1) listening activity by using songs; 2) filling gap of a paragraph; 3) answering true/false sentences; 4) filling gap of a conversation; 5) answering multiple choice questions based on a story; 6 ) guessing words or things based on the description or clues; 7) obeying instruction; 8) answering essay questions based on a conversation; 9) answering multiple questions based on a text; 10 ) answering multiple choice questions based on a conversation; 11) detecting mistakes of sentences in a text and a conversation; 12) ticking off items/activities/places; 13) arranging a phrase or a simple sentence from instructions. All these listening activities were implemented in the exercises of the developed supplementary listening materials.
In analyzing the four main potencies of local wisdom in Bali, the information of the aspects and the parts of each aspect were obtained from several websites in the internet and books, such as, from Asti (2017) about Balinese foods, Supeksa (2015) about Balinese household furniture, Fiddinna (2016) and Kawul (2014) about Balinese traditional clothes for men and women, Nuansa Blog (2013) about Balinese songs for children, a list arranged by Remaja Kerokhanian Sapta Darma (2014) about a list of traditional medicine and medicine plants, Leise Magazine by Suarja and Rik (2003) about Subak or Balinese traditional water irrigation system, and the books from Krishna (2010) about four potency of local wisdom in Bali, Tri Hita Karana and Tri Murti related to Balinese belief system, and Balinese ceremonies and traditions, and Rai, et al (2016) about kinds of Balinese local fruits.

The local wisdom of Bali was also inserted as basic information or content on the exercises of the developed listening materials in order to implement a contextual learning for the eighth grade students at SMP Negeri 2 Singaraja and to relate some other aspects of local wisdom of Bali to the students as one way to communicate using English without losing the identity as Balinese in order to maintain or preserve and learn the values of the culture and other aspects of local wisdom of Bali. It was also claimed by Udayanti, Putra, and Artini (2017) in their study that the context of learners' culture was used in developing media and materials in order to help them connect English with their background knowledge. It is in line with Sehe, Tolla, Kamaruddin and Hamsa (2016) who conducted a study on the development of language learning materials based on local wisdom claimed that the development of learning materials based on local wisdom was important to introduce and cultivate the values of local wisdom in the region of the students, it can challenge them to explore the knowledge of local wisdom in their own region, and studying learning materials based on local wisdom is an initial way to understand and recognize the values of local wisdom that have been less instilled in the 
younger generation (Kurniawati, Wahyuni \& Putra, 2017).

Second, the processes of developing this supplementary listening materials were (a) analyzing needs from the English syllabus to find topics need to be developed for listening materials, the four potencies of local wisdom of Bali, and analyzing the present situation at SMP Negeri 2 Singaraja through the results of teachers' interview, class observation, and students' questionnaire, (b) designing a blue print of the product based on the results of syllabus analysis, teachers' interview, class observation, and students' questionnaire, (c) developing the blue print into a complete product which consisted of audio recordings (CD-RW), printed listening materials, and answer key and listening scripts, (d) evaluating the product was the last process done by four expert judges by using a scoring rubric. Third, to find the quality of the developed product, it was measured by four expert judges using a scoring rubric. The result of product evaluation was shown on Table 1.

Table 1: The Total Score of Product Evaluation from the Four Experts

\begin{tabular}{cccc}
\hline Items (52) & PART A & PART B & TOTAL \\
\hline Total score of Expert 1 & 106 & 146 & 252 \\
Total score of Expert 2 & 102 & 138 & 240 \\
Total score of Expert 3 & 104 & 147 & 251 \\
Total score of Expert 4 & 104 & 142 & 246 \\
\hline \multicolumn{2}{c}{ TOTAL SCORE } & & 989 \\
\hline
\end{tabular}

Based on the total score of four experts on Table 1, it was found that the total score of the four expert judges was 989 ( $\bar{X} \geq 936=$ Excellent) which was categorized as excellent material. Thus, the developed materials can be categorized as an excellent product. Some suggestions and input from the four expert judges that were filled on the scoring rubric became the consideration in revising some points in the developed listening materials. Several points that have been revised based on suggestions of four expert judges were about the follow-up activity of the listening game, language use, grammar on the learning instruction on each unit and the working instruction on each exercise, and a list of typical Balinese vocabulary was provided in the developed materials in order to help the students in understanding the content on the exercises.

The outcome of this study was the product which was in the form of audio recording (CD-RW) and the printed listening materials along with the answer key and listening scripts. The printed supplementary listening materials and audio recording consisted of seven units. Each unit in the printed supplementary listening materials covered the title or topic, competences to be achieved, learning instruction, content of learning materials, grammar focus, pronunciation focus, exercises, working instructions of each exercise, and assessment of the exercises.

The developed English supplementary local wisdom-based listening materials have three characteristics. First, the potencies of the local wisdom of Bali were inserted as basic information on the exercises of each unit. The contents of the exercises, such as texts, conversations, descriptions, short story, songs were based on the potencies and aspects of the local wisdom of Bali. These potencies were inserted in order to learn how to use English to communicate globally without losing the identity as Balinese who have diversity in terms of their local wisdom. Second, the audio recording of the developed materials was developed by using native-like speaker voices in order to create natural and real language use for the eighth-grade students and to replace teacher's voice used previously in the listening activity. Native-like speaker voices were produced by a text-to-speech application called Natural Reader 14. Third, it was user-friendly for the English teachers and the eighth-grade 
students at SMP Negeri 2 Singaraja. The English teachers who taught the eighth-grade students at SMP Negeri 2 Singaraja can easily use the developed listening materials in teaching because it contained the audio recording of pronunciation focus, exercises and the answer key along with the listening scripts. For students, in using the listening materials, the instruction of each exercise was explained clearly using easy words for them so they can understand the instruction well. It also provided some expressions related to a topic on each unit which were used on the exercises in order to make them understand what they have listened to easily.

\section{CONCLUSIONS}

Regarding to research questions proposed, the findings and discussion, it can be concluded that (1) there were seven topics that needed to be developed in the English supplementary local wisdom-based listening materials, such as giving and responding to compliment; asking and giving opinions; asking and giving information about ability and willingness; asking and giving information about a must, prohibition and suggestion; asking and giving instruction, invitation, and permission; asking and giving information about special events/days; and asking and giving information about location, things and animals; (2) the processes of developing the materials were (a) analyzing the English syllabus and four potencies of local wisdom of Bali, (b) designing a blue print of the product, (c) developing a blue print into a complete listening materials, and (d) evaluating the developed product done by four expert judges; (3) the result of product evaluation done by the four expert judges showed that the quality of the developed product was categorized as excellent materials. The outcome of this study was the product which was in the form of audio recording (CDRW) and the printed listening materials along with the answer key and listening scripts. It is also suggested to the other researchers who are interested in developing the same topic of materials to do the research in developing listening materials for other grades in order to provide a variety of listening materials, for examples, for the ninth grade students and for other topics besides the seven topics covered in the developed supplementary listening materials in this study.

\section{REFERENCES}

Asti. (2017). 32 Makanan khas Bali-Kenikmatan wisata kuliner di Bali [Thirty two kinds of Balinese traditional foods-The enjoyment of culinary in Bali]. Retrieved from http://www.pergiberwisata.com/makana n-khas-bali/

Fiddinna, A. (2016). How to wear Balinese traditional clothing appropriately. Retrieved from http://fiddinnaabloggy.blogspot.co.id/20 16/05/normal-0-false-false-false-en-us-xnone.html

$\mathrm{Hu}, \mathrm{X}$. (2012). The application of schema theory in College English listening teaching. Theory and Practice in Language Studies, 2(2), 282-288. Retrieved from http://www.academypublication.com/iss ues/past/tpls/vol02/02/11.pdf.

Kawul. (2014). Bali-Tarian adat, rumah adat, pakaian adat, senjata tradisional, makanan tradisional, alat musik tradisional dan lagu daerah [BaliTraditional dances, traditional house, traditional clothes, traditional weapons, traditional foods, traditional musical instruments, \& traditional songs]. Retrieved from http://kawulala.blogspot.co.id/2014/12/t arian-adat-rumah-adat-pakaianadat_76.html

Krishna, A. (2010). The wisdom of Bali: The sacred science of creating heaven on earth. Jakarta: Gramedia Pustaka Utama.

Kurniawati, A. A., Wahyuni, S., \& Putra, P. D. A. (2017). Utilizing of comic and Jember's local wisdom as integrated science learning materials. International Journal of Social Science and Humanity, 7(1), 4750. Retrieved from http://www.ijssh.org/vol7/793HS0071.pdf 
Mahaputri, D. S. (2017). Fostering listening material based on IELTS test for Collage students. The Fifth International Seminar on English Language Teaching, 5(4), 3542, ISSN: 2580-1287. Retrieved from http://ejournal.unp.ac.id/index.php/selt/ article/view/7981/6084

Nawangsasi, E. (2015). Developing listening materials for the eighth grade students of SMPN 14 Yogyakarta based on 2013 Curriculum (Master's thesis, English Language Education, Universitas Negeri Yogyakarta). Retrieved from http://eprints.uny.ac.id/23679/1/ESTHI\% 20NAWANGSASI\%20(10202241041).pdf

Nuansa Blog. (2013). 13 lirik lagu daerah Bali beserta maknanya dan video lirik lagu [Thirteen kinds of Balinese traditional songs with their meaning and videos of the song lyrics]. Retrieved from https://arumsuci.blogspot.co.id/2017/07 /13-iirik-lagu-daerah-bali-beserta.html

Oakes, J. (2002). Assess to textbooks, instructional materials, equipment, and technology: Inadequacy and inequality in California's public school. California: UCLA's Graduate School of Education and Information Studies. Retrieved from http://www.schoolfunding.info/resource _center/legal_docs/California/Williams_E xperts_Reports/Williams_Oakes_report_ 2_InstructMaterials.pdf.

Padmanugraha, A. S. (2010, May). Common sense outlook on local wisdom and identity: A contemporary Javanese native's experience. Paper presented at International Conference on "Local wisdom for character building" at Auditorium Building, YSU. Retrieved from http://eprints.uny.ac.id/4036/1/Common _Sense_Outlook_on_Local_Wisdom_and _Identity_A_Contemporary_Javanese_N ative\%EF\%BF\%BD\%2580\%2599s_Experie nce.pdf.

Qodir, A., Baehaqi, L., \& Miftah, M. Z. (2016). Developing materials of listening comprehension for the English department students. Journal on English as a Foreign Language, 6(1), 1-20.
Retrieved from http://e-journal.iainpalangkaraya.ac.id/index.php/jefl/article /download/379/631.

Rai, I N., Wijana, G., Sudana, I P., Wiraatmaja, I W., Semarajaya, C. G. A. (2016). Buahbuahan lokal Bali: Jenis, pemanfaatan dan potensi pengembangannya. Denpasar: Percetakan Pelawa Sari.

Rakhmawati, I., Iragiliati, E., \& Rachmajanti, S. (2016). Developing supplementary multimedia-based listening materials for the seventh grades. Jurnal Pendidikan: Teori, Penelitian dan Pengembangan, 1(5), 940-947. Retrieved from http://journal.um.ac.id/index.php/jptpp/ article/download/6325/2698

Remaja Kerokhanian Sapta Darma. (2014). Daftar tanaman obat herbal Indonesia [A list of Indonesian herbal medicinal plants]. Retrieved from https://agrobahanjamu.files.wordpress.c om/2015/04/daftar-tanaman-obat-danketerangannya.pdf

Renukadevi. D. (2014). The role of listening in language acquisition: The challenges \& strategies in teaching listening. International Journal of Education and Information Studies. 4(1), 59-63. Retrieved from https://www.ripublication.com/ijeisv1n1 /ijeisv4n1_13.pdf

Richey, R. C., \& Klein, J. D. (2007). Design and development research. Mahwah, New Jersey: Lawrence Erlbaum Associates, Publishers.

Sehe, Tolla, A., Kamaruddin, \& Hamsa, A. (2016). The development of Indonesian language learning materials based on local wisdom of the first grade students in Sma Negeri 3 Palopo. Journal of Language Teaching and Research, 7(5), 913-922. Retrieved from www.academypublication.com/issues/jltr /vol07/jltr0705.pdf

Suarja, I. G., \& Rik, T. (2003, September). Traditional water management in Bali. Leisa Magazine. Retrieved from https://www.researchgate.net/publicatio 

n/237798402_Traditional_water_manag
ement_in_Bali

Sukandi, S. S. (2013). Teaching writing to Indonesian EFL students: Challenges of the "voice" and "style" in adjusting cross cultural communication skills. Proceedings International Seminar of Language Teaching in Cross Cultural Communication Context. Retrieved from https://www.academia.edu/5838001/Te aching_Writing_to_Indonesian_EFL_Lear ners_Challenges_of_the_Voice_and_Styl e_in_Adjusting_Cross_Cultural_Communi cation_Skills

Supeksa, K. (2015). Istilah-istilah perkakas/perabotan dalam Bahasa Bali [Terms of tools or equipments in Balinese]. Retrieved from http://www.pecintaipa.info/2016/12/istil ah-istilah-perkakas-perabotan.html

Syafi'i, M. L. (2016). Developing listening materials for the tenth graders. JEELS, 3(1), 63-84. Retrieved from http://jurnal.stainkediri.ac.id/index.php/j eels/article/view/174.

Udayanti, L. M., Putra, I N. A. J., \& Artini, L. P. (2017). Developing thematic English visual media based on character education for the fourth grade students in SDN 1 Pancasari (Master's thesis, English Language Education, Ganesha University of Education) 